\title{
RACHEL IS FIRST PRESIDENT OF LINDSAY SOCIETY
}

Rachel Bairsto, the British Dental Association's (BDA's) Head of Museum Services, was elected President of the Lindsay Society for the History of Dentistry at the Society's annual conference in Durham.

Rachel, who joined the BDA Museum staff in 2003, is the first President of the Lindsay Society following the change in name of office from Chairman to President. The new chain of office, which incorporates the logo of the Society, was presented by Past Chairman Dr Stuart Geddes (pictured, left) and Dr Stuart Robson (right) who generously donated the chain of office to the Society.

Delegates at the conference enjoyed a variety of presentations from Roger Forshaw on dental archaeology; Professor Stanley Gelbier on the London Dental Hospital; Barry Berkovitz on 'Nothing but the Tooth' and 'Dentistry in Art' by DFT Rebecca Little. This was followed by a visit to Beamish Open Air Museum to view the Victorian dental surgery.

For further details about the Lindsay Society and to join please contact the Secretary, Brian Williams, on brianwilliams14@ btinternet.com.

www.bda.org/museum

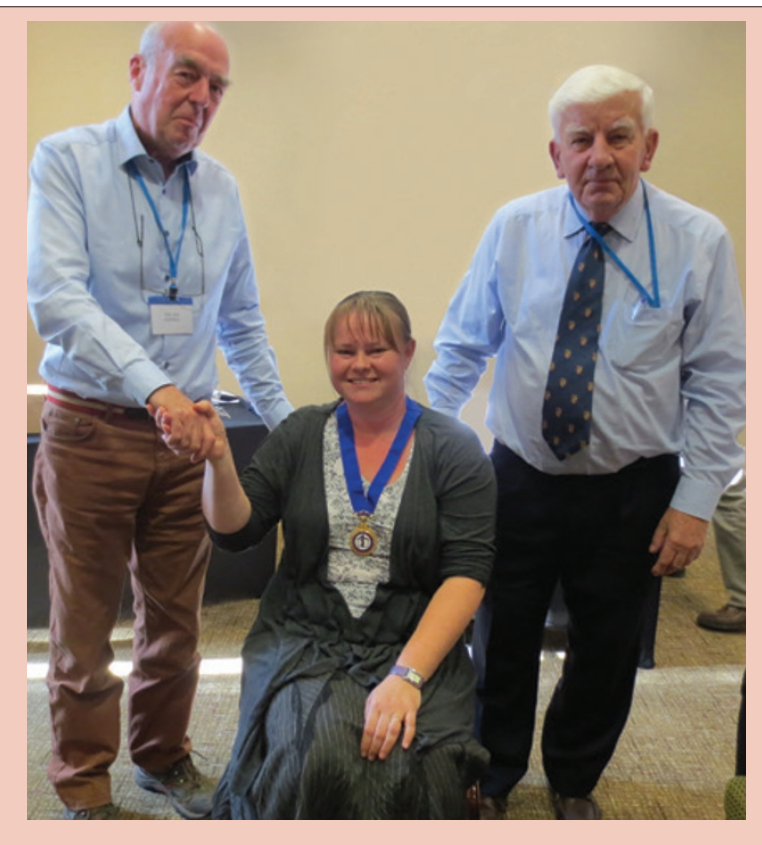

\section{OVER HALF OF DENTAL NURSES HAVE HAD A NEEDLESTICK INJURY}

Just over half of dental nurses in the UK and the Republic of Ireland have had a needlestick injury at some stage in their career.

This is a finding of a survey conducted by the British Association of Dental Nurses (BADN) in conjunction with Initial Medical, healthcare waste management experts. The survey was conducted online between June-August 2014 and received 1,216 responses.

Of those who said they'd received a needlestick injury, 60\% said they'd received more than one, with $11 \%$ saying they'd been injured in the past year. In terms of when their injury occurred, $41 \%$ of respondents who'd had a sharps injury said their last injury had happened after use, before disposal.

Encouragingly, 97.4\% of those who'd received an injury knew what steps to take. Out of all survey respondents, 52\% rated their needlestick injury training as very good, with 29\% rating it good. Interestingly, 21\% of UK respondents said that since the Health ct Safety (Safe Instruments in Healthcare) Regulations 2013 came into force, their practice had not put in place new safety procedures or safety devices.

Of those who'd had an injury, $1.24 \%$ said they'd acquired a blood-borne virus as a result.

\section{BOOK REVIEW}

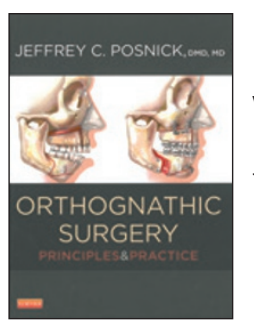

ORTHOGNATHIC SURGERY: PRINCIPLES AND PRACTICE. VOLUMES 1 AND 2

J. C. Posnick

Elsevier

price Ł257.00; pp 1,864

ISBN 9781455726981

Gaining an understanding of the interface between oral and maxillofacial surgery and orthodontics is not an easy task. Orthognathic surgery: principles and practice. Volumes 1 and 2 by J. C. Posnick, published by Elsevier, allows the reader to gain a vast amount of knowledge on both subjects and illustrates with great clarity how the two subject areas work together.

The book gives an utterly comprehensive account of the different dentofacial deformities amenable to orthognathic surgery. It discusses the methodology involved in planning these complex treatments, taking the reader through step by step approaches to each surgical procedure and in addition, looks at the long-term outlook and potential complications that can arise for patients in each case.

The text is split into seven sections starting with basic principles and surgical techniques, then working through the multitude of different presentations and considerations in different facial deformity cases. In total there are 1,864 pages in the two volumes and the quality of the publication never falters. For example, Chapter four discusses developmental influences on dentofacial deformity. The relevant anatomical and clinical features are illustrated in the most appropriate way in either pictorial form, CT scan images, clinical photographs and intraoral views depending on the case. The reader is left with no blind spots in their knowledge due to the level of detail in the book.
The treatment planning chapters allow the reader to really understand how to examine and analyse patient facial anatomy, and goes through the laboratory aspects involved in planning the pre-operative and post-operative study casts showing the proposed final result. Surgical treatment sequences are illustrated in pictorial and photographic format - quite literally a step by step approach. In addition there are 45 videos illustrating many of the surgical techniques discussed in the book. The videos are of exceptional clarity and the viewer is guided through the procedure with a running commentary. There is nothing negative to say about this book other than it will consume a lot of your time as you run through its pages.

I imagine that clinicians of all levels of experience will learn something from this book. It includes not only the descriptive factual elements but also the experience of the author, which is shared and supported by evidence and description from hundreds of referenced articles and textbooks. It is an excellent all round educational source for any practitioner and the owner of this text is unlikely to need any other textbook on orthognathic surgery.

J. MURPHY 